\title{
EFFECTS OF FERAL HORSE HERDS ON RANGELAND PLANT COMMUNITIES ACROSS A PRECIPITATION GRADIENT
}

\author{
Lauren E. Baur ${ }^{1}$, Kathryn A. Schoenecker ${ }^{2}$, and Melinda D. Smith ${ }^{3}$
}

\begin{abstract}
AвstRACT.-Feral horses are widespread in the western United States, with the majority of feral horse herds found in the Great Basin. There is a federal mandate to manage these herds in order to maintain "ecological balance"; however, understanding of the specific effects of feral horse grazing on rangeland plant communities in this region is incomplete. To address this research gap, we utilized long-term grazing exclosures and fenceline contrasts to evaluate the impacts of feral horses on several plant community variables (diversity, richness, dominance, and biomass) and species composition. Because the effects of grazing can vary with site precipitation and productivity, we selected 5 sites from 4 different rangeland types (Great Basin Desert, Colorado Plateau, Rocky Mountain grassland, and mixed grass prairie) that spanned a mean annual precipitation gradient of 229 to $413 \mathrm{~mm}$. Our results did not reveal a significant effect of feral horse grazing on plant community composition, species richness, diversity, evenness, or dominance. In contrast, total aboveground herbaceous biomass and grass biomass were significantly reduced with feral horse grazing, but these effects did not vary with mean annual precipitation. Our results suggest that, at least at the sites we studied, feral horses have affected the plant community by reducing herbaceous biomass but have not caused plant community shifts. Additional multisite studies, preferably with standardized exclosures and larger sample sizes, would increase our understanding of feral horse grazing effects and inform management of feral horse herds in the western United States.
\end{abstract}

Resumen.-Al oeste de los Estados Unidos se han dispersado caballos ferales, localizándose, en su gran mayoría, en la Gran Cuenca (Great Basin). Existe una orden federal para administrar estas manadas a fin de mantener el "equilibrio ecológico"; sin embargo, las consecuencias específicas del pastoreo de caballos ferales en los pastizales de esta región de EE.UU. no se conocen por completo. Para abordar esta falta de conocimiento comparamos el uso de zonas exclusivas de pastoreo a largo plazo y áreas de cercado contrastantes, con el fin de evaluar los efectos de los caballos ferales en diversas variables de las comunidades vegetales (diversidad, riqueza, dominio y biomasa) y en su composición. Debido a que los efectos del pastoreo pueden variar según la lluvia y la productividad del lugar, seleccionamos cinco sitios de cuatro tipos diferentes de pastizales (desierto de la Gran Cuenca, meseta de Colorado, praderas mixtas y pastizales de las Montañas Rocosas) que comprendieron un gradiente de precipitación media anual de 229 a 413 mm. Nuestros resultados no revelaron efectos significativos en la composición, la riqueza de especies, la diversidad, la uniformidad o el dominio de la comunidad vegetal, como consecuencia del pastoreo de caballos ferales. Por el contrario, la biomasa por encima del suelo de herbáceas y la biomasa de gramíneas se redujeron significativamente con el pastoreo de caballos ferales, pero estos efectos no variaron con la precipitación media anual. Por lo tanto, nuestros resultados sugieren que, al menos en los sitios que estudiamos, los caballos afectaron a la comunidad vegetal al reducir la biomasa herbácea, pero no provocaron cambios en la comunidad vegetal. Estudios adicionales en otros sitios, preferentemente en zonas exclusivas de pastoreo estandarizadas y con tamaños de muestra más grandes, podrían mejorar nuestra comprensión de los efectos del pastoreo de caballos ferales e informar sobre el control de las manadas de caballos ferales al oeste de los EE.UU.

Feral horses are widespread in the western United States, and their ecological role has been a subject of controversy. The Bureau of Land Management (BLM) manages most feral horse herds in the western United States as dictated by the Wild Free-Roaming Horses and Burros Act of 1971 (Public Law 92-195). This law mandates that the horses be managed in such a way as to "preserve and maintain a thriving natural ecological balance" on the range. While the consequences of cattle grazing on western rangelands have been thoroughly studied (e.g., Kauffman and Krueger 1984, Belsky et al. 1999, Jones 2000), the ecological effects of feral horses have received less attention (Beever 2003, Nimmo and Miller 2007). The effect of feral horses on rangelands west of the Rocky Mountains is of particular importance, given that a large majority of federally managed feral horse herds and herd management areas (HMAs) are found in that region. However, most studies of

\footnotetext{
1Department of Biology, University of New Mexico, Albuquerque, NM 87131. E-mail: lbaur@unm.edu

${ }^{2}$ United States Geological Survey, Fort Collins Science Center, and Department of Ecosystem Science and Sustainability, Colorado State University, Fort Collins, CO 80523

${ }^{3}$ Department of Biology and Graduate Degree Program in Ecology, Colorado State University, Fort Collins, CO 80523.
} 
feral horse grazing effects in North America have been conducted in salt marshes of the East Coast (Turner 1987, 1988, Wood et al. 1987, Furbish and Albano 1994, Seliskar 2003, De Stoppelaire et al. 2004) and a montane habitat in the Pryor Mountain Wild Horse Range of northern Wyoming/southern Montana (Detling 1998, Fahnestock and Detling 2000, Gerhardt 2000, Gerhardt and Detling 2000), with a limited number of studies conducted in the Great Basin (Beever and Brussard 2000, Beever et al. 2003, 2008, Davies et al. 2014, Boyd et al. 2017) or other western rangelands (Crane et al. 1997, Ostermann-Kelm et al. 2009). Thus, we still lack basic understanding of the effects of feral horse grazing on rangelands of the western United States. This deficit represents a critical knowledge gap for effective rangeland management. (For further background on the management of feral horses on federal lands, see Beever [2003] and Scasta et al. [2016].)

Compared to other ungulates, feral horses are expected to differ in their effects on rangeland plant communities because of differences in their digestive anatomy as well as in their grazing behavior. Although horses and cattle share a high dietary overlap (Scasta et al. 2016), horses have higher energy requirements than cattle (Hanley 1982, Duncan et al. 1990). As cecal digesters rather than ruminants, they digest most forage more quickly and less completely (Duncan et al. 1990). Therefore, horses need to eat more plant biomass per unit of body mass than cattle (Janis 1976, Holechek 1988, Duncan et al. 1990, Menard et al. 2002, Scasta et al. 2016). On the other hand, unlike ruminants, equids can live on a high-cellulose diet (Gwynne and Bell 1968, Janis 1976), enabling them to survive and even thrive in habitat that would be considered low quality for other ungulates. Horses also differ from cattle in their grazing behavior. While cattle prefer to stay near water sources (Kauffman and Krueger 1984, Beever 2003), horses are able to range farther from water (Beever and Brussard 2000). Horses also show a preference for steeper and higher-elevation habitats (Ganskopp and Vavra 1986, Crane et al. 1997). This may mean that horses cause less damage than cattle around water sources, but also that plants maintained in high-elevation refuges when only cattle are present are more likely to be grazed when horses are present (Symanski
1994, Beever 2003, Beever and Aldridge 2011). Because of these differences, relying on studies of cattle grazing effects to inform management of feral horse herds and HMAs may not be appropriate. Instead, improved information on the specific effects of feral horse grazing is needed.

While there have been some studies of the effects of feral horses on plant communities in rangelands of the Intermountain West (Beever and Brussard 2000, Beever et al. 2003, 2008, Davies et al. 2014, Boyd et al. 2017), the number of sites that have been studied is small compared to the area over which feral horses are found. Grazing effects on plant communities can be locally specific and dependent on environmental conditions (Milchunas et al. 1988, Menke and Bradford 1992, Hobbs 1996, Ostermann-Kelm et al. 2009, Beever and Aldridge 2011). For example, the magnitude and direction of grazing effects on plant diversity appear to be influenced by the productivity of a site, which is correlated with precipitation level (Milchunas et al. 1988, Milchunas and Lauenroth 1993, Frank 2005, Bakker et al. 2006, Lezama et al. 2014). In productive grasslands, grazing often increases plant diversity, while in less-productive grasslands, grazing can reduce diversity (Bakker et al. 2006, Lezama et al. 2014). In addition, the magnitude of grazing effects tends to increase with increasing productivity (Milchunas and Lauenroth 1993, Lezama et al. 2014). Thus, to more comprehensively understand the impacts of feral horse grazing in the western United States, studies across a range of environmental conditions are needed.

The purpose of our study was to assess the long- and short-term effects of feral horse grazing on plant communities at 5 sites spanning a large portion of the geographic area where feral horses are found in the western United States. These sites covered a range of annual precipitation from 229 to $413 \mathrm{~mm}$ per year. The sites are examples of 4 different rangeland ecosystems: Great Basin Desert, Colorado Plateau, Rocky Mountain grasslands, and mixed grass prairie. In an effort to capture long-term effects, we selected sites with preexisting exclosures or fenceline contrasts. Because of previous studies showing such a relationship between grazing effects and productivity or precipitation, we hypothesized that horse grazing would increase plant 
species richness and diversity at more mesic sites and decrease them at more xeric sites. We also predicted that, as observed by Milchunas and Lauenroth (1993) and Lezama et al. (2014), the magnitude of grazing effects would increase with increasing precipitation.

\section{Methods}

\section{Study Sites}

We selected 5 semiarid rangeland sites (Table 1) that had preexisting exclosures or fencelines separating areas grazed by feral horses from areas not grazed by feral horses. Length of treatment (i.e., time since the exclosures or fences were constructed) ranged from about 10 years at the Colorado site to 81 years at the Utah site. Sites spanned a precipitation gradient from approximately $229 \mathrm{~mm}$ per year in Nevada to $413 \mathrm{~mm}$ per year in Colorado (Fig. 1). Because most of our sites were remote and lacked long-term precipitation records, we used interpolated mean annual precipitation from the Terrestrial Precipitation Analysis package (TPA) (Lemoine et al. 2016b) to define where each site fell along a precipitation gradient.

\section{Experimental Design}

Because we were sampling preexisting exclosures and fencelines of different sizes, sampling layout varied slightly between sites (see Table 1). Clan Alpine (CA), Pryor Mountain (PM), and Spring Creek Basin (SCB) had preexisting grazing exclosures, and data were collected inside and outside each exclosure. CA differed from the other sites in that its exclosures were built to protect springs. In 2014 our sampling protocol at CA was similar to that of Beever and Brussard (2000); that is, we located species composition transects inside exclosures at exclosed springs and in grazed areas at nearby springs without exclosures. In 2015 we added transects immediately outside the exclosures at the exclosed springs so that the data from CA would be more directly comparable to the data from the other sites.

Sulphur and Theodore Roosevelt (THRO) did not have preexisting grazing exclosures, but each site had an established fenceline with horses confined to one side. Sulphur HMA was separated by a fenceline from the U.S. Forest Service's Desert Experimental Range (DER); horses grazed on the BLM side but not the DER side. At THRO, we sampled in the park's South Unit, where the horses were confined inside the park fence and mostly on the east side of the Little Missouri River, which bisects the park. In 2014 we placed transects on either side of the river. In 2015 we added transects on either side of the park fence. Because of their different establishment dates and the distance between them, we treated these 2 groups of transects as separate sites for analysis (THRO1 and THRO2).

\section{Species Composition Sampling}

To assess plant species composition, we recorded absolute percent cover of all plant species within $1 \times 1-m$ quadrats placed every $2 \mathrm{~m}$ along transects inside and outside the permanent exclosures or on either side of the fenceline or river. Transects were located at least $12 \mathrm{~m}$ (at SCB) and as many as $50 \mathrm{~m}$ (at Sulphur and THRO2) away from the fenceline or exclosure to avoid bias caused by the tendency of ungulates to travel along fencelines or to be attracted to exclosures. Most transects were $50 \mathrm{~m}$ long, but at SCB the exclosures were too small for that length, so we used multiple shorter transects. Some larger exclosures had multiple $50-\mathrm{m}$ transects inside to increase sampling. For each quadrat, we visually estimated aerial cover of each species separately to the nearest $1 \%$. We also estimated the percent cover of biological soil crust and of totally exposed ground covers, including bare ground, rock, and litter, where they exceeded a contiguous $1 \%$ of the quadrat. Species composition data were collected at each site once in 2014 and twice in 2015 (early and late in the growing season, to capture peak cover of both early- and late-growing species). The maximum cover value for each species in 2015 was used in subsequent analyses.

\section{Fecal Transects}

To estimate utilization of our sampling sites by herbivores, we established dung transects in 2015. Each transect consisted of two 50-m tapes placed $4 \mathrm{~m}$ apart and running parallel to our species composition transects. These were located either outside exclosures or on the side of the fence with horses at each site except THRO1. One transect at Sulphur and 2 at THRO2 were also placed on the side of the fence without horses. In May/June we cleared all large animal dung from the area between 


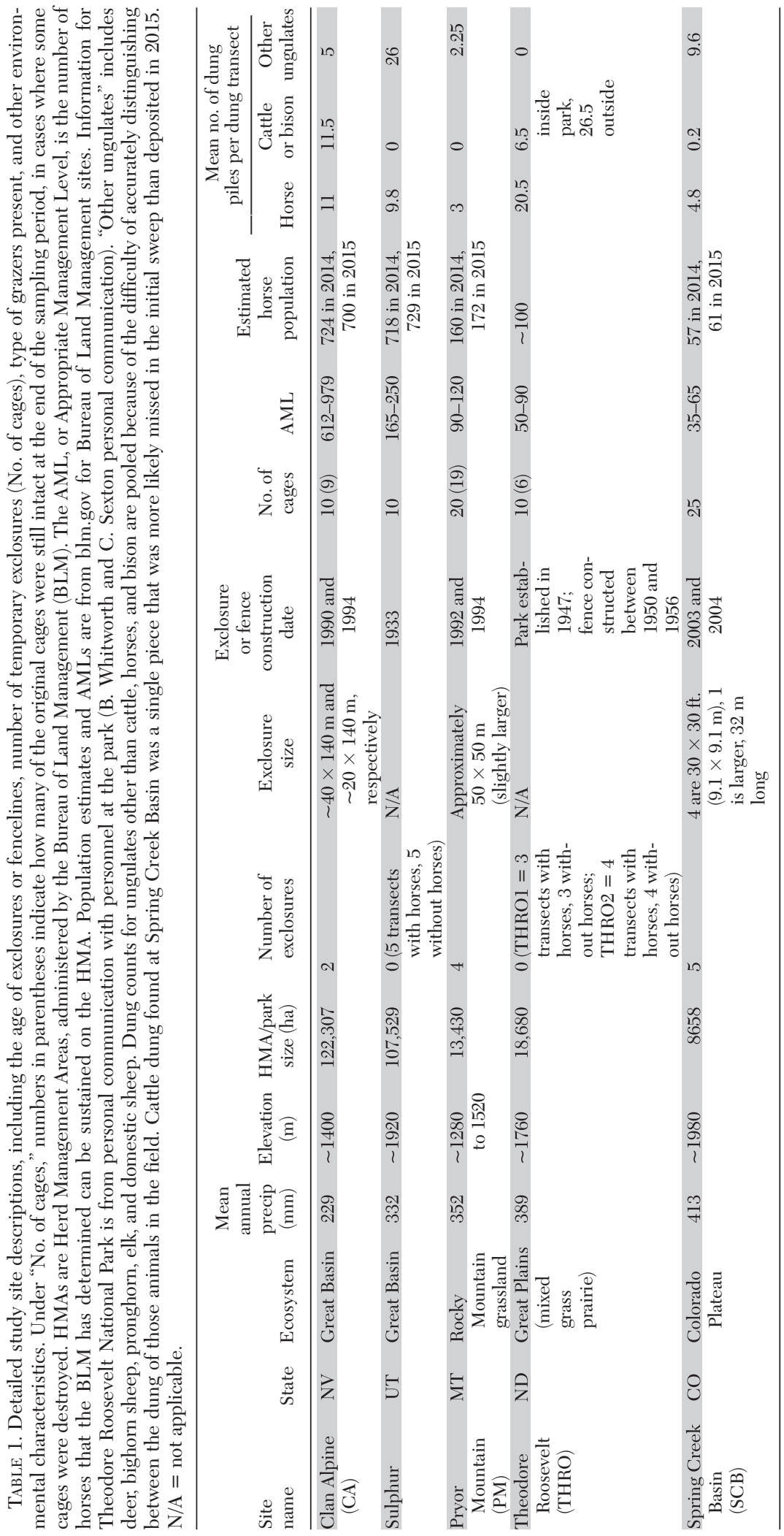




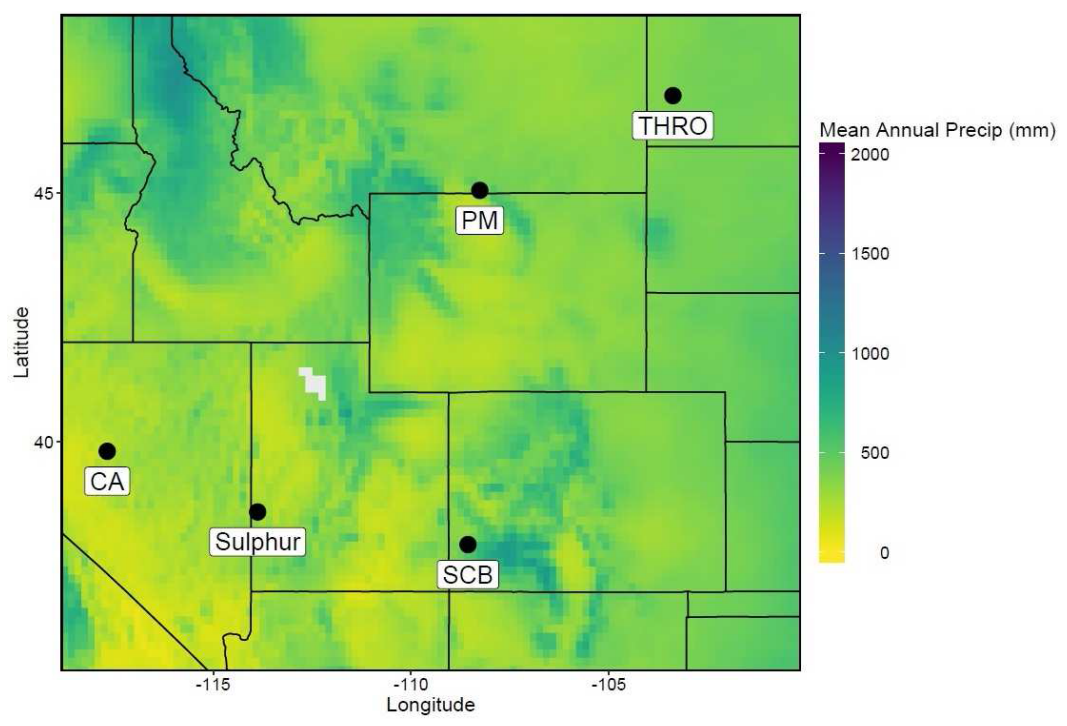

Fig. 1. Map of vegetation sampling site locations and precipitation levels across the western USA, 2014-2015. CA = Clan Alpine Herd Management Area, Sulphur = Sulphur Herd Management Area, SCB = Spring Creek Basin Herd Management Area, PM = Pryor Mountain Wild Horse Range, THRO = Theodore Roosevelt National Park. See Table 1 for more information on each site.

the tapes and recorded the number of dung piles. We repeated this process near the end of the growing season (August/September) to determine the number of dung piles added. No statistical analyses were performed on these data; instead, we used average number of piles per transect as a general metric of herbivore presence (see Table 1).

\section{Biomass Sampling}

To measure short-term grazing impacts, we constructed small temporary exclosures ("cages"), each $1 \times 1 \times 1 \mathrm{~m}$ in size, and installed them outside permanent exclosures or in horse-grazed areas at each site in spring 2015. In late summer, we collected all aboveground herbaceous biomass inside $0.25-\mathrm{m}^{2}$ circular clipping quadrats. For each cage, we clipped one quadrat inside the cage, one quadrat approximately 1-2 $\mathrm{m}$ outside the cage, and one quadrat inside the permanent exclosure or on the side of the fenceline without feral horses. At the time the cages were placed, we determined where to place each outside clipping quadrat by comparing the area up to approximately $2 \mathrm{~m}$ away from the cage on each of its 4 sides and choosing the side of each cage that had the most plant species in common with the area inside the cage. Since we were not collecting biomass from woody plants, we avoided placing the cages and their corresponding outside clipping quadrats directly on top of shrubs. If multiple sides of the cage had the same species in common with the area inside the cage, the side that was most similar in biomass to the area inside the cage, based on a visual estimate at the time the cages were installed, was chosen. Clipping quadrats inside the permanent exclosures were placed by randomly tossing them into the exclosure or adjacent to the species composition transect on the side of the fenceline without horses. Quadrats were clipped to ground level where they fell. Biomass was separated into grass and forb categories. Biomass was field-dried and then dried in drying ovens in the lab for at least $24 \mathrm{~h}$ at $60{ }^{\circ} \mathrm{C}$ before weighing.

\section{Statistical Analysis}

For species composition data, the experimental unit for analysis was a plot. Most plots consisted of 25 quadrats, but some plots had as few as 12 or as many as 75 quadrats. In most cases, each plot consisted of all quadrats inside or outside a single permanent exclosure. At Sulphur, each 50-m transect was considered a plot, meaning the site had a total of 5 plots with horse grazing and 5 plots without. At THRO1 each plot consisted of 3 transects 
(meaning there was only 1 plot per treatment), and at THRO2 each plot consisted of 2 transects (2 plots per treatment). Transects were grouped into plots based on their proximity to each other. At Sulphur, transects were roughly evenly spaced along the fenceline, while at THRO1 and THRO2, transects were more clustered due to topography.

Mean species richness, Pielou's evenness, diversity $\left(\mathrm{e}^{\mathrm{H}^{\prime}}\right)$, and Berger-Parker dominance were calculated for each individual quadrat, then the mean values of each variable per quadrat within each plot were used in analysis. We chose to average across all quadrats within each plot, rather than calculating community variables at the plot level, to reduce bias caused by the fact that not all plots had an equal number of quadrats. Species richness was defined as the number of species present in the quadrat. Pielou's evenness is Shannon's diversity divided by the natural log of species richness. Berger-Parker dominance is the relative cover of the most abundant species in the quadrat. Diversity was computed as the numbers equivalent of the Shannon diversity index because this measure behaves in a more intuitive way than the Shannon diversity index itself (Jost 2006, Jost 2007). Because of differences in sampling between the 2 years of the study, 2014 and 2015 data were analyzed separately. An $\alpha$-level of 0.1 was set for all analyses.

Plant species richness, evenness, diversity, and dominance were analyzed using a mixed linear model with PROC MIXED in SAS ${ }^{\circledR}$ version 9.4 (SAS Institute Inc., Cary, NC). Factors were site and grazing (i.e., feral horses present or not), with the grazing treatment nested within site. A similar mixed linear model was used to analyze grass, forb, and total herbaceous biomass (excluding previous years' dead litter) inside and outside permanent exclosures or fencelines. In both models, effects of grazing treatment, site, and treatment $\times$ site interactions were assessed.

The layout used for species composition sampling at Clan Alpine differed from that used at other sites in that some grazed plots did not have corresponding ungrazed plots; therefore, some data could not be used in the analyses to assess site or grazing effects. Because of this, CA was not included in statistical analysis for 2014. For 2015 sampling, new transects were added, and the 2 grazed plots at CA without corresponding ungrazed plots were dropped from the analysis for 2015 .

To assess differences in plant community composition, community matrices were constructed, consisting of relativized mean percent cover per quadrat of each species in each plot. These community matrices were used to calculate Bray-Curtis resemblance matrices. The resemblance matrices were analyzed using 2-factor PERMANOVAs (Primer v6), with site and treatment (with vs. without horses) as factors, with treatment nested within site.

Short-term grazing effects/utilization (i.e., differences in biomass inside vs. outside temporary exclosures) were analyzed in SAS using Wilcoxon nonparametric tests (PROC NPAR1 WAY) because not all sites and treatments met the assumptions for $t$ tests. Biomass was averaged across all temporary exclosures and all corresponding grazed plots for each site, and those averages were used to calculate percentage growing season offtake $(100 *$ [ungrazed grazed]/ungrazed) for each site in 2015 (McNaughton 1979, Bonham 1989).

\section{REsults}

\section{Plant Community Response to Feral Horse Grazing}

Richness, diversity $\left(\mathrm{e}^{\mathrm{H}^{\prime}}\right)$ and dominance, but not evenness, varied significantly by site for both years of the study (Table 2, Figs. 2, 3). However, there were no significant grazing effects, and grazing $\times$ site interactions were not significant (Table 2).

Two-factor PERMANOVAs showed that plant community composition differed significantly among the 5 study sites $(P=0.005$ for both 2014 and 2015). However, plant community composition was not different between grazed and ungrazed plots $(P=0.987$ for 2014 and $P=0.969$ for 2015 ). Individual singlefactor PERMANOVAs performed separately for each site in each year also failed to find any significant effect of grazing on community composition at any individual site $(P>0.1$, data not shown).

\section{Long-term Effects of Feral Horse Grazing on Biomass}

Averaging across all treatments (inside permanent exclosures, inside temporary exclosures, and outside), THRO had by far the highest total biomass, followed by CA, SCB, 


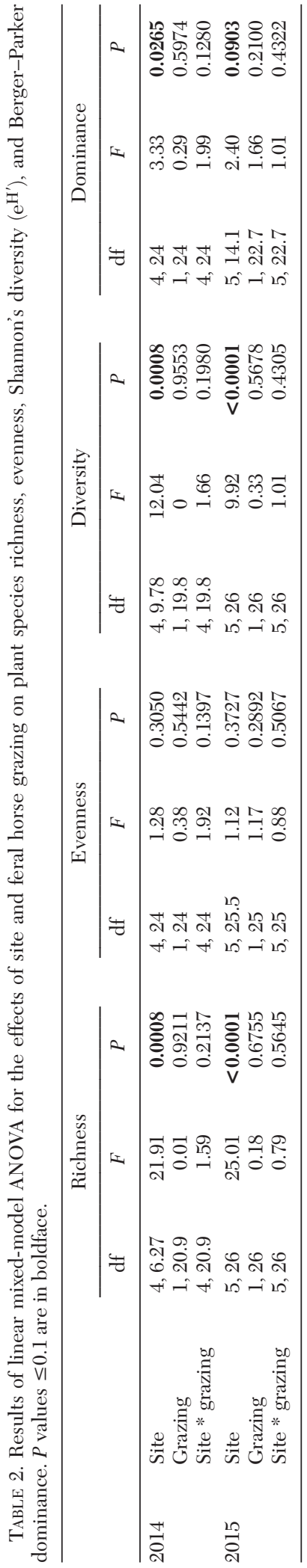

PM and Sulphur (Fig. 4). Total biomass and grass biomass differed significantly by site and with grazing (Table 3). Forb biomass did not differ significantly between sites or with grazing, and interactions between site and grazing were not significant for total, grass, or forb biomass.

Across sites, grazed areas had on average $52.9 \%$ less grass biomass and $40.3 \%$ less total biomass than areas experiencing long-term exclusion from horse grazing. (Note these percentages are calculated as percent removed; see Table 4.) CA was an outlier with $95.3 \%$ less grass biomass outside than inside permanent exclosures.

\section{Short-term Grazing Intensity and Annual Utilization}

Percent offtake of total biomass over the 2015 growing season was highest at PM $(26.3 \%)$ and lowest at THRO (1.9\%). At Sulphur, average biomass was higher outside than inside temporary exclosures by $52.7 \%$. However, based on $P$ values from 2-tailed Wilcoxon nonparametric tests, none of the differences in grass, forb, or total biomass inside versus outside the temporary exclosures were statistically significant at any site $(P>0.1$, data not shown).

\section{Discussion}

Over the 2-year study period, we did not observe a significant effect of grazing by feral horses on plant species richness, diversity, evenness, dominance, or plant community composition for the 5 rangeland sites spanning a 184-mm precipitation gradient. Conversely, based on comparisons with long-term exclosed areas, feral horse grazing significantly reduced grass biomass and total biomass, but this effect did not vary among sites. Thus, our hypothesis that grazing effects would vary by site according to precipitation levels was not supported.

Although the effects of grazing on plant species richness, diversity, evenness, and dominance were not significant, some trends were observed. At PM and SCB, in both years, grazing was associated with lower dominance and higher richness, evenness, and diversity (see Table 5). Both of those sites are dominated by palatable grasses, so it makes sense that grazing would decrease dominance, allowing for higher diversity. On the same 

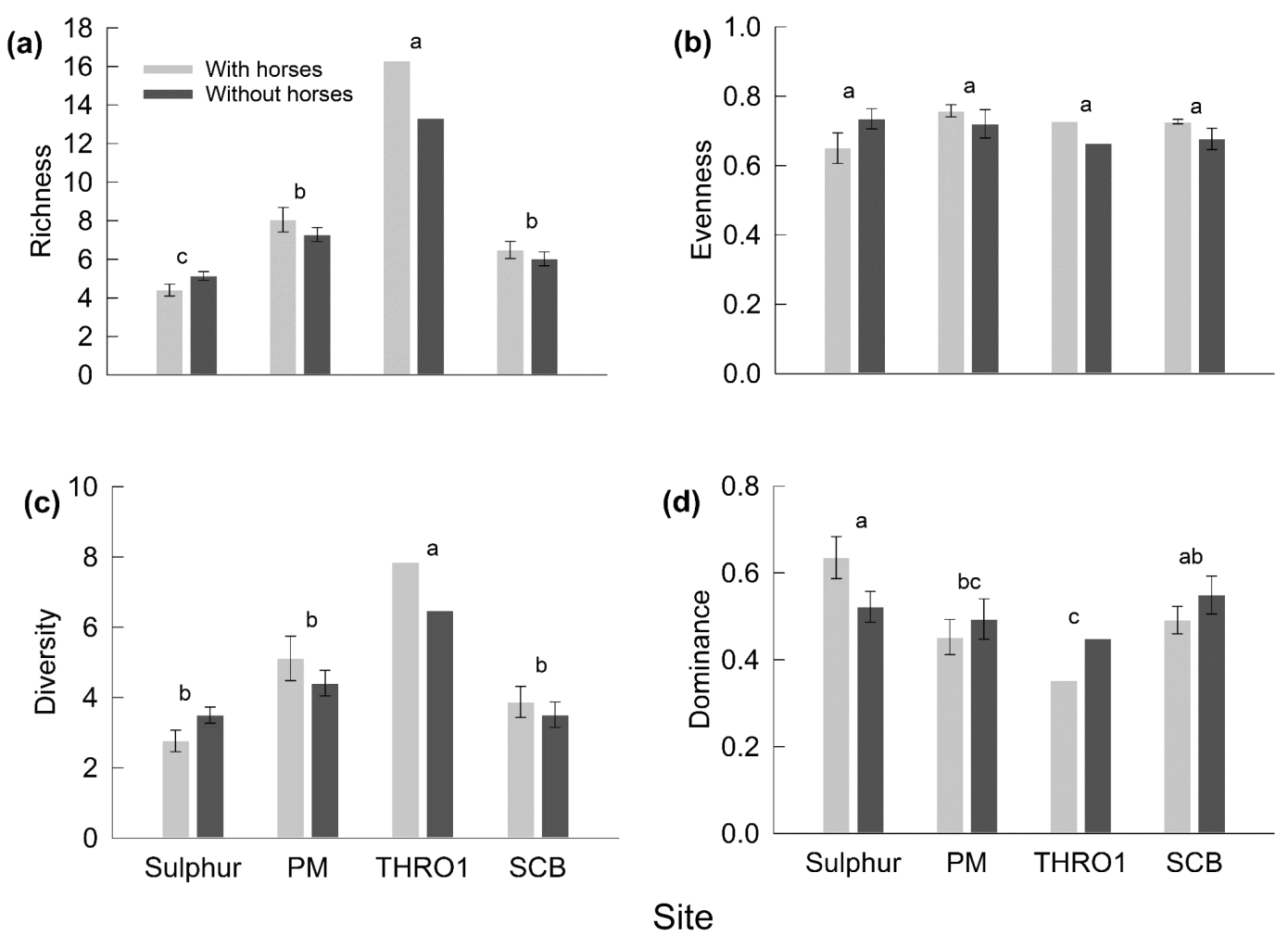

Fig. 2. Comparisons of (a) plant species richness, (b) Pielou's evenness, (c) numbers equivalent of Shannon's diversity $\left(\mathrm{e}^{\mathrm{H}^{\prime}}\right)$, and (d) Berger-Parker dominance $\mathrm{m}^{-2}$ (i.e., per square meter) in 2014 (mean $\pm \mathrm{SE}$ ) in areas with feral horse grazing (lighter bars) and areas under long-term protection from feral horse grazing (darker bars). Different lowercase letters denote significant differences between sites at $\alpha=0.1$. (No significant differences between treatments were found.) Sites are in order from driest (lowest precipitation) to wettest (highest precipitation).

note, at Sulphur, a site dominated by shrubs unpalatable to horses, horse grazing was associated with higher dominance and lower richness, evenness, and diversity. At THRO1 and CA, dominance and evenness were both higher in grazed areas, while richness and diversity were lower. This result is likely attributable at least in part to confounding factors, such as proximity to springs, rather than simply due to feral horse grazing. (See discussion of study limitations below.)

Similar to our study, previous studies of feral horse impacts have often found that horse grazing reduced overall aboveground plant biomass. These include de Villalobos and Zalba (2010) in grasslands in Argentina and Wood et al. (1987), Turner (1987, in a study where clipping was used to simulate feral horse grazing), and Seliskar (2003) on east coast barrier islands. Wood et al. (1987) also observed lower grass biomass in areas grazed by feral horses. However, in previous studies at PM, one of the sites included in our study, Gerhardt and Detling (2000) found no significant effect of horses on total biomass, and Fahnestock and Detling (1999a) found that grasses compensated for biomass removed by simulated horse grazing when water availability was adequate.

Studies assessing the effects of horses on plant species richness and diversity are more numerous, but with more varied results. In some cases, horses reduce both plant species richness and diversity (de Villalobos and Zalba 2010). In others, horses have been found to have no effect on plant species richness (Seliskar 2003) or to increase plant diversity (Ostermann-Kelm et al. 2009). Among previous studies at PM, Gerhardt and Detling (2000) and Gerhardt (2000) found no effect on plant species richness, but Fahnestock and Detling (1999b) found that horses increased 

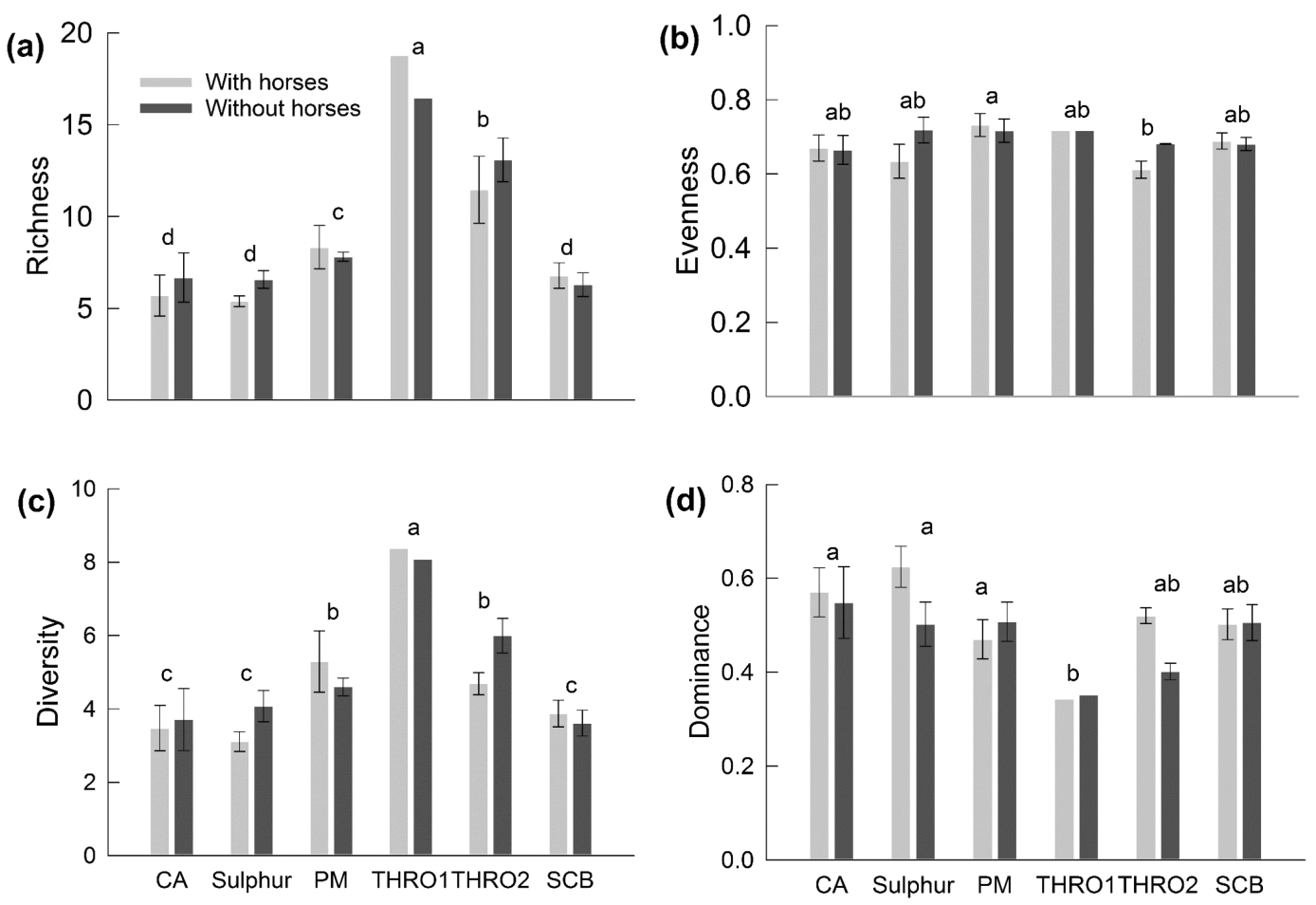

\section{Site}

Fig. 3. Comparisons of (a) plant species richness, (b) Pielou's evenness, (c) numbers equivalent of Shannon's diversity $\left(\mathrm{e}^{\mathrm{H}^{\prime}}\right)$, and (d) Berger-Parker dominance $\mathrm{m}^{-2}$ (i.e., per square meter) in 2015 (mean $\pm \mathrm{SE}$ ) in areas with feral horse grazing (lighter bars) and areas under long-term protection from feral horse grazing (darker bars). Different lowercase letters denote significant differences between sites at $\alpha=0.1$. (No significant differences between treatments were found.) Sites are in order from driest (lowest precipitation) to wettest (highest precipitation).

diversity in some cases. In the Great Basin the presence of feral horses has usually been associated with lower plant species richness (Beever and Brussard 2000, Beever et al. 2008) and diversity (Davies et al. 2014). However, Beever et al. (2008) found increased species richness at some horse-occupied sites, while Davies et al. (2014) found no effect of horses on richness. Similar to our study, Beever et al. (2003) in the Great Basin and Detling (1998) at PM found that horse grazing was not a major influence on plant community composition.

There are several possible reasons for the lack of significant effects on plant diversity metrics and species composition in our study. Arid and semiarid rangelands often display nonequilibrium or nonlinear responses to grazing (Westoby et al. 1989, Friedel 1991, Laycock 1991, Joyce 1993). These unpredictable dynamics can obscure relationships between grazing and plant community variables
(Westoby et al. 1989, Friedel 1991, Laycock 1991, Joyce 1993). The productivity level of our sites may also have contributed to the lack of observed grazing effects. Assuming that there is a relationship between primary productivity and the effects of grazing on plant diversity, with grazing decreasing diversity at less productive sites and increasing diversity at more productive sites, this implies an intermediate range of productivity where little to no effect of grazing on plant diversity is observed. Our sites may fall into such a range of intermediate productivity where grazing has no observable effect on plant diversity. It is also possible that the horse populations at our sites were too low to cause plant community shifts, but shifts might occur at higher population densities.

It is also possible that plant community changes have occurred which our sampling did not detect. Because we used only preexisting 

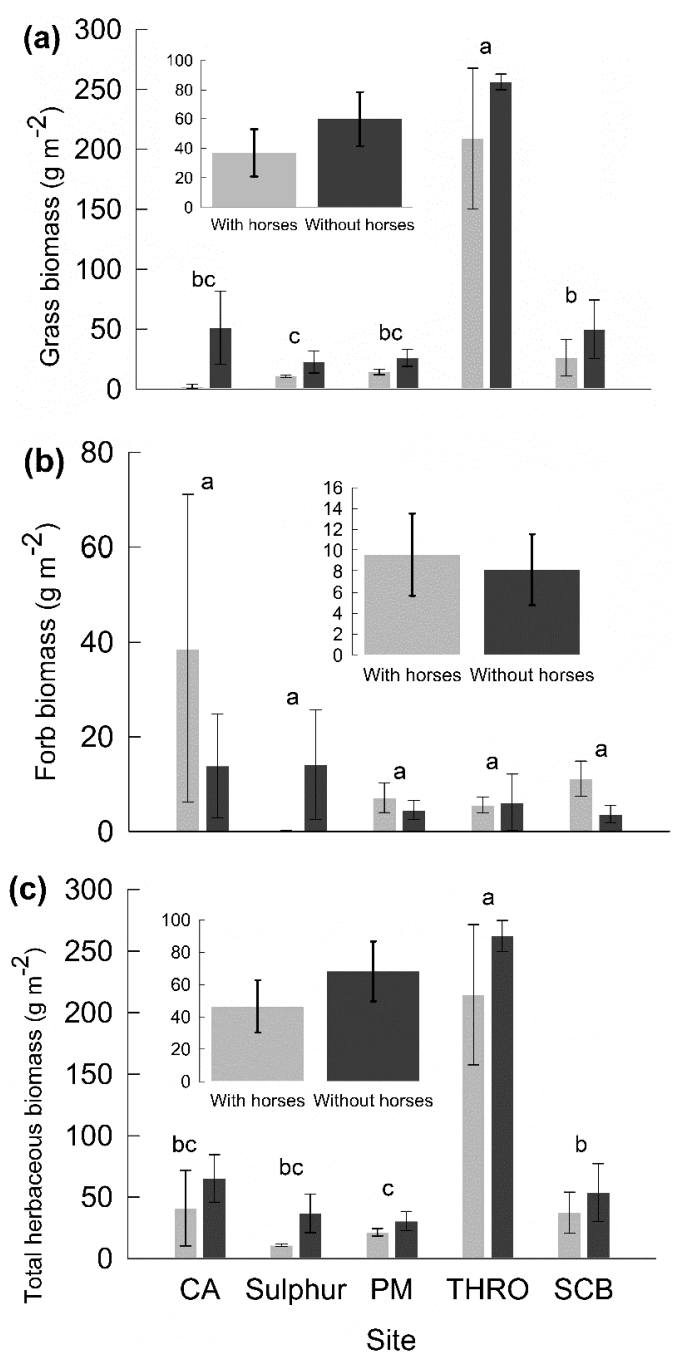

Fig. 4. Comparisons of (a) grass, (b) forb, and (c) total herbaceous biomass, measured in 2015 (mean $\pm \mathrm{SE}$ ) in areas with feral horse grazing (lighter bars) and areas under long-term protection from feral horse grazing (darker bars). Error bars represent one standard error. Different lowercase letters denote significant differences between sites at $\alpha=0.1$ (see Table 3). Insets show differences in biomass averaged across all sites (mean $\pm \mathrm{SE}$ ). fencelines and exclosures, our sample size at each site was limited. An inherent problem with small sample size is the potential for type II errors (failure to detect an effect that truly exists), as well as type $\mathrm{M}$ errors (overestimation of effect sizes when significant effects are observed) (Lemoine et al. 2016a). Small sample sizes are a common weakness of exclosure studies, due in part to the difficulties and costs of constructing and maintaining large numbers of exclosures (Bock et al. 1993). In addition to the problems associated with small sample size, our inability to standardize the size, number, and placement of exclosures also created unbalanced data and potentially introduced bias. Bias may also have been introduced by the differing ages of the exclosures and fences and other confounding factors such as proximity to springs at CA.

The presence of herbivores other than horses may also have influenced our results (see Table 1). Most notably, at CA our fecal transects indicated that roughly equal numbers of horses and cattle were present near our plots, meaning that grazing effects at CA should be regarded as resulting from a combination of horse and cattle use. Similarly, at THRO2, where bison were present inside the park fence and cattle were present outside, we hoped that the functional similarity between cattle and bison grazing (Knapp et al. 1999, Tastad 2013) would allow us to detect the additional impact of horse grazing inside the fence (see Table 1). However, based on dung counts, cattle use of transects outside the fence exceeded bison use of transects inside the fence, potentially causing the data at THRO2 to underestimate the impact of horses. Similarly, we cannot be sure whether or when the fences we sampled had been breached in the past and grazing exclusion compromised. At Sulphur, some breaches had recently been

TABLE 3. Results of mixed-model ANOVA for the effects of site and feral horse grazing on grass, forb, and total herbaceous biomass (comparing grazed areas with areas inside permanent exclosures or on the side of a fenceline where feral horses were not present). $P$ values $\leq 0.1$ are in boldface.

\begin{tabular}{|c|c|c|c|c|c|c|c|c|c|}
\hline \multirow[b]{2}{*}{2015} & \multicolumn{3}{|c|}{ Grass } & \multicolumn{3}{|c|}{ Forbs } & \multicolumn{3}{|c|}{ Total } \\
\hline & $\mathrm{df}$ & $F$ & $P$ & df & $F$ & $P$ & $\mathrm{df}$ & $F$ & $P$ \\
\hline Site & $4,6.57$ & 23.01 & 0.0006 & 4,1 & 0.89 & 0.6520 & $4,7.87$ & 18.34 & 0.0005 \\
\hline Grazing & $1,22.7$ & 5.1 & 0.0338 & $1,21.7$ & 0.09 & 0.7634 & $1,23.1$ & 3.96 & 0.0586 \\
\hline Site*grazing & $4,22.7$ & 0.48 & 0.7481 & $4,21.7$ & 1.53 & 0.2298 & $4,23.1$ & 0.26 & 0.9005 \\
\hline
\end{tabular}


TABLE 4. Long-term grazing effects on grass and total biomass inside versus outside permanent exclosures at each site. Percent removed is calculated as $100 *$ (ungrazed grazed)/ungrazed, where "ungrazed" is biomass inside permanent exclosures or on the side of a fenceline where feral horses were not present, and "grazed" is biomass outside exclosures or on the side of a fenceline where feral horses were present.

\begin{tabular}{lccccc}
\hline & \multicolumn{2}{c}{ Log response ratio } & & \multicolumn{2}{c}{ Percent removed } \\
\cline { 2 - 3 } Site & Grass & Total & & Grass & Total \\
\hline CA & -3.05911 & -0.58321 & & $95.3 \%$ & $44.2 \%$ \\
Sulphur & -0.68856 & -1.16463 & & $49.8 \%$ & $68.8 \%$ \\
PM & -0.59923 & -0.37607 & & $45.0 \%$ & $31.3 \%$ \\
THRO & -0.31058 & -0.30964 & & $26.7 \%$ & $26.6 \%$ \\
SCB & -0.64418 & -0.36088 & & $47.5 \%$ & $30.3 \%$ \\
MEAN & -1.06033 & -0.55889 & & $52.9 \%$ & $40.3 \%$ \\
\hline
\end{tabular}

made by elk, but this was reportedly not a problem before 2013 (Stanley Kitchen personal communication). At CA, comparison with photos and descriptions from Beever and Brussard (2000) indicated that fencing had been replaced and the exclosures possibly expanded since that research was conducted.

Despite the limitations of our study, our results provide evidence that at the sites we studied feral horses are reducing plant biomass but are not changing plant community composition. Our research might also be regarded as a case study in the difficulties associated with quantifying the effects of feral horses on western rangelands. If future research can overcome these problems, it would provide much-needed data on the effects of feral horses and the connections between those effects and environmental conditions.

One way to better address the question of how feral horses affect vegetation would be a large-scale, long-term study with standardized exclosures. The National Research Council, in its 2013 report on the BLM Wild Horse and Burro Program, suggested designating and intensively studying "sentinel HMAs [...] representative of diverse ecological settings." In keeping with this suggestion, a study could include sites throughout the geographic extent of feral horses on Bureau of Land Management lands and at a range of elevations, because elevation strongly affects temperature and precipitation in the Great Basin (Houghton 1979, Petersen 1994, Beever et al. 2003, Soulard 2006). This would enable investigation of a larger precipitation gradient to potentially detect relationships between

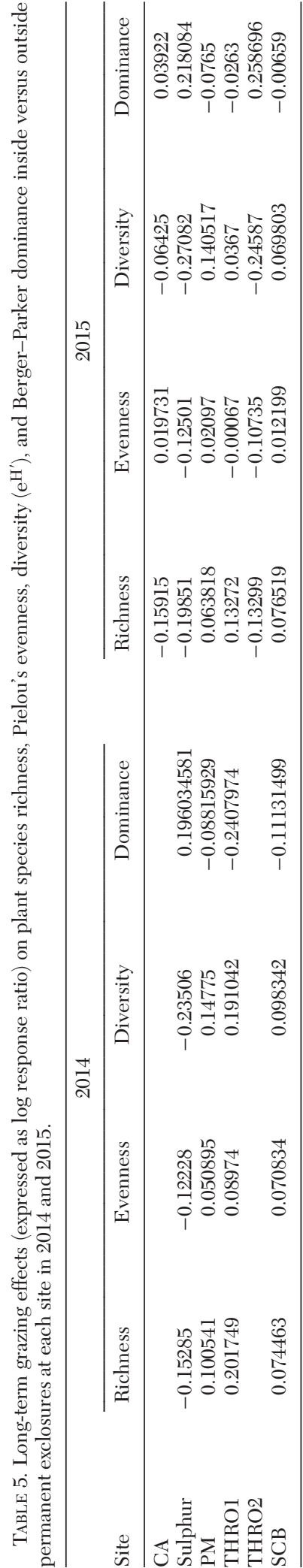


precipitation and grazing effects. As mentioned previously, many feral horse exclosure studies have suffered from small sample sizes. A system of large exclosures with standardized dimensions, with multiple exclosures per site, would be extremely valuable for studying feral horse impacts.

Moreover, given that feral horse grazing often occurs in tandem with cattle, sheep, and native ungulate grazing, there is a pressing need for studies that separate the effects of feral horses from those of other herbivores. A study targeting HMAs without cattle or bison, or HMAs where grazers could be separated, would reduce the confounding effects of those grazers. It would also be helpful to select locations where both the history of livestock grazing and the horse population (past and current numbers and habitat use) are well documented. This would enable investigation of relationships between horse density/grazing intensity and grazing effects, a question which is critical to wild horse management.

Thus, despite the challenges of studying ecological effects of feral horses, a large-scale, long-term study of carefully selected HMAs using large, standardized exclosures could go a long way toward addressing the questions and controversy surrounding this topic and could contribute to optimal management of feral horse herds in the United States.

\section{ACKNOWLEDGMENTS}

Thanks to Paul Meiman for his advice throughout the project. Mariah Patton's assistance with fieldwork was extremely helpful. Abby Lock, Jennie Hawkins, and Claire Griebenow helped with weighing biomass. Many people at the Bureau of Land Management, U.S. Forest Service, National Park Service, and U.S. Geological Survey provided administrative help and advice, including John Axtell, Bill Pickett, Jared Bybee, Jim Sparks, Mike Jensen, Stan Kitchen, Elizabeth Burghard, Bill Whitworth, Chad Sexton, Martina Thornton, and Erik Beever. We thank the USGS Fort Collins Science Center for the use of equipment and added field support to collect data. Phil Turk and Nathan Lemoine helped with data analysis. Jesse Gray and T.J. Holmes helped with fieldwork, and Jennifer Ackerfield helped with plant identification. Thanks to 2 anonymous reviewers for their helpful comments.

\section{Literature Cited}

Bakker, E.S., M.E. Ritchie, H. Olff, D.G. Milchunas, AND J.M.H. KNOPS. 2006. Herbivore impact on grassland plant diversity depends on habitat productivity and herbivore size. Ecology Letters 9:780-788.

BeEver, E. 2003. Management implications of the ecology of free-roaming horses in semi-arid ecosystems of the western United States. Wildlife Society Bulletin 31:887-895.

BeEver, E.A., AND C.L. Aldridge. 2011. Influences of free-roaming equids on sagebrush ecosystems, with a focus on Greater Sage-Grouse. Pages 272-290 in S.T. Knick and J.W. Connelly, editors, Greater SageGrouse: ecology and conservation of a landscape species and its habitats. Studies in Avian Biology, volume 38. University of California Press, Berkeley, CA.

Beever, E.A., AND P.F. Brussard. 2000. Examining ecological consequences of feral horse grazing using exclosures. Western North American Naturalist 60: 236-254.

Beever, E.A., R.J. Tausch, and P.F. Brussard. 2003. Characterizing grazing disturbance in semiarid ecosystems across broad scales, using diverse indices. Ecological Applications 13:119-136.

Beever, E.A., R.J. Tausch, and W.E. Thogmartin. 2008. Multi-scale responses of vegetation to removal of horse grazing from Great Basin (USA) mountain ranges. Plant Ecology 196:163-184.

Belsky, A.J., A. Matzke, and S. Uselman. 1999. Survey of livestock influences on stream and riparian ecosystems in the western United States. Journal of Soil and Water Conservation 54:419-431.

Bock, C.E., J.H. Bock, AND H.M. Sмith. 1993. Proposal for a system of federal livestock exclosures on public rangelands in the western United States. Conservation Biology 7:731-733.

Bonham, C.D. 1989. Measurements for terrestrial vegetation. 2nd edition. Wiley-Blackwell.

Boyd, C.S., K.W. Davies, and G.H. Collins. 2017. Impacts of feral horse use on herbaceous riparian vegetation within a sagebrush steppe ecosystem. Rangeland Ecology and Management 70:411-417.

Crane, K.K., M.A. Smith, and D. Reynolds. 1997. Habitat selection patterns of feral horses in southcentral Wyoming. Journal of Range Management 50: 374-380.

Davies, K.W., G. Collins, and C.S. Boyd. 2014. Effects of feral free-roaming horses on semi-arid rangeland ecosystems: an example from the sagebrush steppe. Ecosphere 5:1-14.

De Stoppelaire, G.H., T.W. Gillespie, J.C. Brock, and G.A. Tobin. 2004. Use of remote sensing techniques to determine the effects of grazing on vegetation cover and dune elevation at Assateague Island National Seashore: impact of horses. Environmental Management 34:642-649.

DetLing, J.K. 1998. Mammalian herbivores: ecosystemlevel effects in two grassland national parks. Wildlife Society Bulletin 26:438-448.

de Villalobos, A.E., and S.M. Zalba. 2010. Continuous feral horse grazing and grazing exclusion in mountain Pampean grasslands in Argentina. Acta Oecologia 36:514-519.

Duncan, P.D., T.J. Foose, I.J. Gordon, C.G. GaKahu, AND M. LLOYD. 1990. Comparative nutrient extraction 
from forages by grazing bovids and equids: a test of the nutritional model of equid/bovid competition and coexistence. Oecologia 84:411-418.

Fahnestock, J.T., AND J.K. DetLing. 1999a. Plant responses to defoliation and resource supplementation in the Pryor Mountains. Journal of Range Management 52:263-270.

Fahnestock, J.T., and J.K. Detling. 1999b. The influence of herbivory on plant cover and species composition in the Pryor Mountain Wild Horse Range, USA. Plant Ecology 144:145-157.

Fahnestock, J.T., and J.K. Detling. 2000. Morphological and physiological responses of perennial grasses to long-term grazing in the Pryor Mountains, Montana. American Midland Naturalist 143: 312-320.

Frank, D.A. 2005. The interactive effects of grazing ungulates and aboveground production on grassland diversity. Oecologia 143:629-634.

Friedel, M.H. 1991. Range condition assessment and the concept of thresholds: a viewpoint. Journal of Range Management 44:422-426.

Furbish, C.E., AND M. Albano. 1994. Selective herbivory and plant community structure in a mid-Atlantic salt marsh. Ecology 75:1015-1022.

GansKopp, D., and M. VAVRa. 1986. Habitat use by feral horses in the northern sagebrush steppe. Journal of Range Management 39:207-212.

Gerhardt, T. 2000. Plant cover species richness in the Pryor Mountain Wild Horse Range-1998. Pages 63-69 in F.J. Singer and K.A. Schoenecker, editors, Managers' summary-Ecological studies of the Pryor Mountain Wild Horse Range, 1992-1997. U.S. Geological Survey, Midcontinent Ecological Science Center, Fort Collins, CO.

Gerhardt, T., AND J. Detling. 2000. Summary of vegetation dynamics at the Pryor Mountain Wild Horse Range-1992-1996. Pages 3-36 in F.J. Singer and K.A. Schoenecker, editors, Managers' summaryEcological studies of the Pryor Mountain Wild Horse Range, 1992-1997. United States Geological Survey, Midcontinent Ecological Science Center, Fort Collins, CO.

Gwynne, M.D., AND R.H.V. BeLl. 1968. Selection of vegetation components by grazing ungulates in the Serengeti National Park. Nature 220:390-393.

Hanley, T.A. 1982. The nutritional basis for food selection by ungulates. Journal of Range Management 35:146-151.

HobBs, N.T. 1996. Modification of ecosystems by ungulates. Journal of Wildlife Management 60:695-713.

HoleCHEK, J.L. 1988. An approach for setting the stocking rate. Rangelands 10:10-14.

Houghton, J.G. 1979. A model for orographic precipitation in the north-central Great Basin. Monthly Weather Review 107:1462-1475.

JANIS, C. 1976. The evolutionary strategy of the Equidae and the origins of rumen and cecal digestion. Evolution 30:757-774.

Jones, A. 2000. Effects of cattle grazing on North American arid ecosystems: a quantitative review. Western North American Naturalist 60:155-164.

Jost, L. 2006. Entropy and diversity. Oikos 113:363-375.

JosT, L. 2007. Partitioning diversity into alpha and beta components. Ecology 88:2427-2439.

JoyCE, L.A. 1993. The life cycle of the range condition concept. Journal of Range Management 46:132-138.
Kauffman, J.B., and W.C. Krueger. 1984. Livestock impacts on riparian ecosystems and streamside management implications . . . a review. Journal of Range Management 37:430-438.

Knapp, A.K., J.M. Blair, J.M. Briggs, S.L. Collins, D.C. Hartnett, L.C. Johnson, and E.G. Towne. 1999. The keystone role of bison in North American tallgrass prairie. BioScience 49:39-50.

LAYCOCK, W.A. 1991. Stable states and thresholds of range condition on North American rangelands: a viewpoint. Journal of Range Management 44:427-433.

Lemoine, N.P., A. Hoffman, A.J. Felton, L. Baur, F. Chaves, J. Gray, Q. Yu, and M.D. Smith. 2016a. Underappreciated problems of low replication in ecological field studies. Ecology 97:2554-2561.

Lemoine, N.P., J. Sheffield, J.S. Dukes, A.K. KnapP, AND M.D. SMith. 2016b. Terrestrial precipitation analysis (TPA): a resource for characterizing longterm precipitation regimes and extremes. Methods in Ecology and Evolution 7:1396-1401.

Lezama, F, S. Baeza, A. Altesor, A. Cesa, E.J. ChaneTON, AND J.M. PARUelo. 2014. Variation of grazinginduced vegetation changes across a large-scale productivity gradient. Journal of Vegetation Science 25:8-21.

McNaughton, S.J. 1979. Grazing as an optimization process: grass-ungulate relationships in the Serengeti. American Naturalist 113:691-703.

Menard, C., P. Duncan, G. Fleurance, J. Georges, and M. LILA. 2002. Comparative foraging and nutrition of horses and cattle in European wetlands. Journal of Applied Ecology 39:120-133.

Menke, J., And G.E. BRadFord. 1992. Rangelands. Agriculture, Ecosystems and Environment 42:141-163.

Milchunas, D.G., and W.K. Lauenroth. 1993. Quantitative effects of grazing on vegetation and soils over a global range of environments. Ecological Monographs 63:327-366.

Milchunas, D.G., O.E. Sala, and W.K. Lauenroth. 1988. A generalized model of the effects of grazing by large herbivores on grassland community structure. American Naturalist 132:87-106.

National Research Council. 2013. Using science to improve the BLM Wild Horse and Burro Program: a way forward. National Academies Press, Washington, DC.

Nimmo, D.G., AND K.K. Miller. 2007. Ecological and human dimensions of management of feral horses in Australia: a review. Wildlife Research 34:408-417.

Ostermann-Kelm, S.D., E.A. Atwill, E.S. Rubin, L.E. Hendrickson, AND W.M. Boyce. 2009. Impacts of feral horses on a desert environment. BMC Ecology 9:22.

Petersen, K.L. 1994. Modern and Pleistocene climatic patterns in the west. Pages 27-53 in K.T. Harper, L.L. St. Clair, K.H. Thorne, and W.M. Hess, editors, Natural History of the Colorado Plateau and Great Basin. University Press of Colorado, Niwot, CO.

SCAsta, J.D., J.L. BECK, AND C.J. Angwin. 2016. Metaanalysis of diet composition and potential conflicts of wild horses with livestock and wild ungulates on western rangelands of North America. Rangeland Ecology and Management 69:310-318.

SELISKAR, D.M. 2003. The response of Ammophila breviligulata and Spartina patens (Poaceae) to grazing by feral horses on a dynamic mid-Atlantic barrier island. American Journal of Botany 90:1038-1044. 
Soulard, C.E. 2006. Land cover trends of the Central Basin and Range ecoregion. Scientific investigations report 2006. U.S. Geological Survey, Reston, VA.

Symanski, R. 1994. Contested realities: feral horses in outback Australia. Annals of the Association of American Geographers 84:251-269.

TASTAD, A.C. 2013. The relative effects of grazing by bison and cattle on plant community heterogeneity in northern mixed prairie. Master's thesis, University of Manitoba.

Turner, M.G. 1987. Effects of grazing by feral horses, clipping, trampling, and burning on a Georgia salt marsh. Estuaries 10:54-60.

Turner, M.G. 1988. Simulation and management implications of feral horse grazing on Cumberland
Island, Georgia. Journal of Range Management 41: 441-447.

Westoby, M., B. Walker, and I. Noy-Meir. 1989. Opportunistic management for rangelands not at equilibrium. 42:266-274.

Wood, G.W., M. MengaK, and M.T. Murphy. 1987. Ecological importance of feral ungulates at Shackleford Banks, North Carolina. American Midland Naturalist 118:236-244.

Received 23 March 2017 Accepted 17 October 2017 Published online 30 January 2018 